\title{
Ambient sulfur dioxide could have an impact on testicular volume from a observational study on a population of infertile male
}

\author{
Yu-An Chen ${ }^{1,2}$, Yi-Kai Chang ${ }^{1}$, Yann-Rong Su ${ }^{3}$ and Hong-Chiang Chang ${ }^{1 *}$ (D)
}

\begin{abstract}
Background: The effect of ambient pollutants on the male reproductive system is controversial. This retrospective study investigated the effect of environmental pollutants on male reproductive health.

Methods: Male patients with primary infertility $(n=282)$ were identified from a single center between January 2016 and December 2017. Patients were physically examined for the presence of varicocele and for the volume of both testicles. Semen quality was measured in terms of the total sperm count, sperm concentration, and the percentage of sperm cells with motility and normal morphology. Data were acquired on the concentration of ambient pollutants, namely particulate matters of diameter $<2.5 \mu \mathrm{m}$, sulfur dioxide $\left(\mathrm{SO}_{2}\right)$, nitrogen oxides $\left(\mathrm{NO}_{x}\right)$, and ozone $\left(\mathrm{O}_{3}\right)$, measured on daily and hourly basis, from the Environmental Protection Administration Executive Yuan, Taiwan. Individual exposure to pollutants was estimated based on the reported residential address of each participant. Statistical analysis indicated the effect of each pollutant on the testicular volume, sex hormone profile, and semen parameters.

Results: The mean \pm standard deviation of age was $36.7 \pm 7.3$ years. The average sperm count and concentration were 41.9 million/mL and 34.1 million/mL, respectively. The mean levels of serum testosterone, follicle-stimulating hormone, and luteinizing hormone were $3.57 \pm 1.68 \mathrm{ng} / \mathrm{mL}, 7.59 \pm 6.3 \mathrm{IU} / \mathrm{L}$, and $4.68 \pm 3.49 \mathrm{IU} / \mathrm{L}$, respectively. According to the multivariate linear regression model, $\mathrm{NO}_{x}$ exposure was a risk factor for decreased sperm concentration and motility $(p=0.043$ and 0.032$)$. Furthermore, $\mathrm{SO}_{2}$ exposure was negatively associated and testicular volume $(p<0.01)$.

(Continued on next page)
\end{abstract}

\footnotetext{
* Correspondence: changhong@ntu.edu.tw

The maps depicted in Figs. 1-4 are adapted from the datasets of the National Land Surveying and Mapping Center MOI 2019-20, which is available to the public under the Open Government Data Licenses and is licensed under the Creative Commons Attribution-Share Alike 4.0 International license.

'Department of Urology, National Taiwan University Hospital and National Taiwan University College of Medicine, No.1, Changde St., Zhongzheng Dist, Taipei City 10048, Taiwan

Full list of author information is available at the end of the article
}

(C) The Author(s). 2020 Open Access This article is licensed under a Creative Commons Attribution 4.0 International License, which permits use, sharing, adaptation, distribution and reproduction in any medium or format, as long as you give appropriate credit to the original author(s) and the source, provide a link to the Creative Commons licence, and indicate if changes were made. The images or other third party material in this article are included in the article's Creative Commons licence, unless indicated otherwise in a credit line to the material. If material is not included in the article's Creative Commons licence and your intended use is not permitted by statutory regulation or exceeds the permitted use, you will need to obtain permission directly from the copyright holder. To view a copy of this licence, visit http://creativecommons.org/licenses/by/4.0/ The Creative Commons Public Domain Dedication waiver (http://creativecommons.org/publicdomain/zero/1.0/) applies to the data made available in this article, unless otherwise stated in a credit line to the data. 
(Continued from previous page)

Conclusions: $\mathrm{NO}_{2}$ and $\mathrm{SO}_{2}$ exposure were negatively associated with the seminal parameter and decreased testicular volume, respectively, in a population of men with infertility. However, additional prospective studies are needed to ascertain the cause-effect relation of current results.

Keywords: Infertility, Air pollution, Sperm quality, Testicular volume

\section{Background}

Following industrialization, increasing attention has been focused on the effects of environmental toxicants on the human reproductive system. Occupational exposure to heavy metals, including arsenic, lead, and mercury, disrupts male reproductive functions through altered sex hormone levels and decreased testicular volume. Furthermore, environmental and occupational exposure to synthetic organic compounds, such as organochlorides and organophosphate, reduce sperm quality. Methyl parathion, a known pesticide, is a type of organophosphate [1-3]. Ambient pollutants resulting from the increasing number of automobiles and factories include particulate matters with aerodynamic diameter $<2.5 \mu \mathrm{m}\left(\mathrm{PM}_{2.5}\right)$, nitrogen oxides $\left(\mathrm{NO}_{\mathrm{x}}\right)$, and sulfur oxides. These ambient pollutants have been shown to not only impair human fertility but also interfere with male reproductive functions [4-10].

Several mechanisms have been proposed to explain how inhaled ambient particles disrupt reproductive function. First, ambient particles could induce oxidative stress (OS) in the gonad along with increased proinflammatory cytokine gene expression [8]. Second, ambient pollutants could interrupt germ cell maturation through altering the expression of the gene regulating differentiation or apoptosis in mice germ cells [11, 12].

Previous studies on the disruption of male reproductive function due to air pollution have almost always only focused on semen quality. The outcomes of other parameters of reproductive function, particularly testicular volume and the presence of varicocele, were not evaluated $[3,13,14]$. Furthermore, the effect of a particular gaseous molecule, for example, sulfur oxides or ozone $\left(\mathrm{O}_{3}\right)$, is still inconclusive, and the results of several studies have been conflicting each another [6, 12, 15-17]. This fueled our interest in conducting a study to evaluate the relationship between ambient pollutants and male reproductive functions based on semen parameters, sex hormone profile, and physical examination, namely examining testicular size and the presence of varicocele.

\section{Methods}

\section{Ethic approval}

The present study followed all standards for ethics regarding the experimentation and research. The institutional review board of the National Taiwan University approved our study and waived the informed consent requirement because of the retrospective design of the present study (approval number: 20190311 RIND).

\section{Study design}

We retrospectively analyzed data from a medical chart database. Patient data were recorded, including age at the time of diagnosis, body mass index (BMI), and lifestyle factors, such as smoking and the presence of diabetes. Furthermore, blood test for fasting blood sugar and sex hormone profile were recorded. At least one semen sample was obtained from each participant. If a patient had more than one semen sample, the first sample was used for the analysis. Air pollution data were acquired from the Environmental Protection Administration Executive Yuan, Taiwan. Outcomes were seminal parameter, sex hormone profile, and change in testicular volume.

\section{Participants}

We analyzed data of men diagnosed with primary infertility obtained from a single center (National Taiwan University Hospital, Taipei, Taiwan) from January 2016 to December 2017. Primary infertility was defined as the inability to conceive under an unprotected sexual encounter in $\geq 12$ months as defined by the World Health Organization (WHO) [18].

Participants with aberrant chromosomes, previous chemotherapy/radiotherapy due to malignancy, or bone marrow transplantation were excluded. Furthermore, patients who were previously diagnosed with obstructive azoospermia, such as the absence of vas deferens or had received vasectomies or orchiectomy, were excluded.

\section{Physical examination}

Physical examination consisted of determining the presence and grading of varicocele and recording the volume of both testicles. The testicular volume was estimated using the Prader orchidometer (Bayer, Müllerstraße 178, Berlin, Germany). Genital malformation, if any, was recorded. Body weight, height, and smoking habits, if any, were recorded.

\section{Blood and hormonal analysis}

Venous blood samples were collected at 9:00-11:00 in the morning. Hormonal assays were conducted in accordance with the instructions of our institute. The testosterone level was recorded in $\mathrm{ng} / \mathrm{mL}$, and luteinizing 
hormone ( $\mathrm{LH}$ ) and follicle-stimulating hormone (FSH) levels were recorded in IU/L.

\section{Semen analysis}

Patients were asked to practice abstinence for 3-5 days before semen collection. Each man was provided a widemouth plastic container. The semen sample was collected through masturbation and was sent to the laboratory at our institute. Each sample was smeared, stained, and preserved. The following semen variables were used as outcomes: total sperm count (million), sperm concentration (million $/ \mathrm{mL}$ ), percentage of motile sperm cells, and the percentage of sperm cells with normal morphology.

\section{Ambient pollutant data and analysis}

Data were acquired from the Environmental Protection Administration Executive Yuan, Taiwan (https://airtw. epa.gov.tw). The concentrations of air pollutants, namely sulfur dioxide $\left(\mathrm{SO}_{2}\right), \mathrm{O}_{3}, \mathrm{NO}_{\mathrm{x}}$ [nitrogen monoxide $(\mathrm{NO})$ and nitrogen dioxide $\left(\mathrm{NO}_{2}\right)$ ], and $\mathrm{PM}_{2.5}$, were automatically recorded at 78 monitoring stations throughout Taiwan. The data collected from these stations were recorded automatically, and the measures were previously validated manually by using linear regression to check concentrations. The concentration of each pollutant was continuously measured on daily and hourly bases. The monthly average of each pollutant was calculated if $\geq 20$ daily average records were available for a month. In this study, individual exposure to air pollution was estimated on the basis of current residential address reported by the study participants and the mean concentrations of air pollutants in the study period (January 2016 to December 2017).

\section{Statistical analysis}

Values are expressed as the mean \pm standard deviation. Linear regression with a regression coefficient $\beta$ and a 95\% confidence interval was applied to indicate the effect of each unit of pollutant on the testicular volume and semen parameter. Smoking and medical comorbidities, including obesity and the varicocele status, were adjusted in the multivariate regression model. Furthermore, we examined the effect of ambient pollutants on sex hormone by using the multivariate linear regression model. Because serum sex hormone is associated with testicular size, an individual linear regression was performed for testicular volume after adjusting for sex hormone. We set the significance level at $p<0.05$. All data analyses were performed using SPSS version 12 (SPSS Inc., Chicago, IL, USA).

\section{Results}

The demographic characteristics of the included participants are summarized in Table $1 \mathrm{a}$ and $1 \mathrm{~b}$. In the study, 282 participants residing in Taiwan were included. The mean ( \pm standard deviation) age, BMI, and the sizes of the right and left testes of all the participants were $36.7 \pm 7.3$ years, $24.6 \pm 4.2 \mathrm{~kg} / \mathrm{m}^{2}$, and $14.18 \pm 2.7$ and $14.30 \pm 2.4 \mathrm{~mL}$, respectively. In total, 64 participants (22\%) had varicocele, and 212 participants (77\%) were nonsmokers. The majority of the participants $(n=265$, 93\%) resided in northern Taiwan; 3,3 , and $1 \%$ of the patients were from central, southern, and other parts of Taiwan, respectively.

\section{Sperm parameters}

The average sperm count was $41.9 \pm 56.6$ million, and the average sperm concentration was $34.1 \pm 38.8$ million/ $\mathrm{mL}$. The percentages of sperms with total motility and normal morphology were $30.5 \pm 16 \%$ and $23.6 \pm 9.2 \%$, respectively (Table 2). The mean values of the total sperm count, concentration, and normal morphology were higher in these participants than the cut-off values according to WHO standards [19]. However, the percentage of the progressively motile spermatozoa was low.

\section{Sex hormone profile}

The sex hormone profile of the study population is summarized in Table 2. The mean levels of serum testosterone, $\mathrm{FSH}$, and $\mathrm{LH}$ were $3.57 \pm 1.68 \mathrm{ng} / \mathrm{mL}, 7.59 \pm 6.3 \mathrm{IU} /$ $\mathrm{L}$, and $4.68 \pm 3.49 \mathrm{IU} / \mathrm{L}$, respectively. The mean

Table 1 a and b. Demographic characteristics of the study participants

\begin{tabular}{|c|c|c|c|}
\hline Characteristics & Mean \pm standard deviation & & Range \\
\hline Age & $36.7 \pm 7.3$ years & & $19-69$ \\
\hline BMI & $24.6 \pm 4.2 \mathrm{~kg} / \mathrm{m}^{2}$ & & $17.3-36$ \\
\hline Right testis & $14.18 \pm 2.7 \mathrm{ml}$ & & $6-20$ \\
\hline Left testis & $14.30 \pm 2.4 \mathrm{ml}$ & & $5-20$ \\
\hline Characteristics & $\mathrm{N}$, total $=282$ & $\%$ & \\
\hline \multicolumn{4}{|l|}{ Cigarette } \\
\hline Smoker & 65 & 23 & \\
\hline Nonsmoker & 217 & 77 & \\
\hline \multicolumn{4}{|l|}{ Varicocele } \\
\hline Present & 64 & 22 & \\
\hline Absent & 218 & 78 & \\
\hline \multicolumn{4}{|l|}{ Residency } \\
\hline Northern Taiwan & 265 & 93 & \\
\hline Central Taiwan & 7 & 3 & \\
\hline Southern Taiwan & 7 & 3 & \\
\hline Other & 3 & 1 & \\
\hline
\end{tabular}


Table 2 Distribution of sperm parameters and sex hormone profile

\begin{tabular}{lll}
\hline & Mean \pm standard deviation & Range \\
\hline Sperm quality parameters & & \\
Sperm count & $41.9 \pm 56.6 \mathrm{mln}$ & $0.25-280$ \\
Sperm concentration & $34.1 \pm 38.8 \mathrm{mln} / \mathrm{ml}$ & $0.1-420$ \\
Sperm motility & $30.5 \% \pm 16 \%$ & $0-75$ \\
Normal form & $23.6 \% \pm 9.2 \%$ & $0-80$ \\
Sex hormone profile & & \\
FSH & $7.59 \pm 6.3 \mathrm{IU} / \mathrm{L}$ & $1.2-56.28$ \\
LH & $4.68 \pm 3.49 \mathrm{IU} / \mathrm{L}$ & $0.32-33.5$ \\
Testosterone & $3.57 \pm 1.68 \mathrm{ng} / \mathrm{mL}$ & $0.98-12.8$ \\
\hline Abbreviations: FSH Follicle Stimulating Hormone $\mathrm{LH}$ Luteinizing hormone
\end{tabular}

testosterone level was higher than the cutoff value of hypogonadism as defined by the American urological association [20].

\section{Air pollution levels}

The average levels of $\mathrm{PM}_{2.5}, \mathrm{O}_{3}, \mathrm{SO}_{2}$, and $\mathrm{NO}_{\mathrm{x}}$ were $18.0 \mu \mathrm{g} / \mathrm{m}^{3} \quad\left(\right.$ range $\left.=10.9-27.2 \mu \mathrm{g} / \mathrm{m}^{3}\right), 27.3 \mathrm{ppb} \quad$ (parts per billion) $\quad($ range $=21.0-40.6 \mathrm{ppb}), 2.9 \mathrm{ppb} \quad($ range $=$ $1.7-5.6 \mathrm{ppb}$ ), and 29.0 (range $=3.7-91.9 \mathrm{ppb}$ ), respectively. According to WHO air quality guidelines, the recommended annual mean for $\mathrm{PM}_{2.5}, \mathrm{O}_{3}, \mathrm{SO}_{2}$, and $\mathrm{NO}_{2}$ were $10 \mu \mathrm{g} / \mathrm{m}^{3}, 100 \mathrm{ppb}, 20 \mathrm{ppb}$, and $40 \mathrm{ppb}$, respectively [21]. Except for $\mathrm{PM}_{2.5}$, the mean concentrations of particulate matter in Taiwan were within reference values suggested by the WHO air quality guidelines. The eastern part of Taiwan, which consists of mostly rural regions, had low $\mathrm{SO}_{2}, \mathrm{NO}_{\mathrm{x}}$, and $\mathrm{PM}_{2.5}$ levels. The distribution of $\mathrm{O}_{3}$ did not considerably vary between the different parts of Taiwan, but a high $\mathrm{O}_{3}$ level was observed in Kinmen, an island located on the east coast of China. All ambient pollutants were at the highest concentration in the southern part of Taiwan, including Tainan, Kaohsiung, and Kinmen, in all seasons. The $\mathrm{PM}_{2.5}$ level was high in winter and low in summer, and the regional concentration difference of $\mathrm{PM}_{2.5}$ was particularly obvious in January and February (Figs. 1, 2, 3, 4, 5).

Tables 3, 4, 5 summarize multiple regression analysis results for the semen parameter, sex hormone profile, and testicular volume after adjusting for blood sugar, BMI, varicocele, and smoking. The exposed mean concentrations of $\mathrm{NO}_{\mathrm{x}}$ in the study period were negatively associated with the sperm concentration and total motility $(p<0.05)$. No statistically significant relationship was observed between exposure to $\mathrm{PM}_{2.5}, \mathrm{SO}_{2}$ or $\mathrm{O}_{3}$ and sperm parameters. In this study, linear regression did not show an effect of ambient pollutant on the sex hormone profile. Only age was found to be an independent predicting factor for increased follicle stimulating hormone (Table 4).

The testicular volume was negatively associated with the exposed mean concentration of $\mathrm{SO}_{2}(p<0.01)$. The effect of $\mathrm{SO}_{2}$ on testicular volume was statistically significant even after adjusting for sex hormone (Table 6).

\section{Discussion}

The current study investigated the effects of air pollutants on the reproductive health of men with infertility. As air pollutants are known to be hazardous to humans, it is unethical to conduct an interventional study on humans. Most studies on the effects of ambient pollutants on humans have been retrospective or observational, and the majority of them focused solely on the effects of pollutants on semen quality $[6,10,13,15-17,22,23]$.

Observational studies analyzing the effect of $\mathrm{SO}_{2}$ and $\mathrm{NO}_{2}$ on sperm quality have reported an unfavorable effect of these ambient particles on the sperm concentration and total count $[9,10,15]$. Our study suggested that $\mathrm{NO}_{2}$ exposure was negatively associated with the sperm concentration and sperm motility, which is consistent with the finding of Broggia [9]. Nevertheless, Zhang reported that $\mathrm{SO}_{2}, \mathrm{NO}_{2}$, and PMs were not associated with poor semen quality [16].

The reported effect of $\mathrm{O}_{3}$ on the reproductive function of men was deleterious. Data obtained from countrywide air quality monitoring showed high $\mathrm{O}_{3}$ exposure to be an independent factor predicting low semen quality, including total sperm count, sperm concentration, and percentage of normal form [16, 22, 24]. However, our results did not show a significant association between $\mathrm{O}_{3}$ and seminal parameters. The inconsistency with the previous literature could be due to the small sample size and retrospective study design, which failed to detect statistically significant effects of $\mathrm{O}_{3}$ on male reproductive function.

The detailed mechanism through which ambient pollutants interfere with the male reproductive system is not well elucidated. One of the most frequently proposed mechanisms is the induction of OS in the reproductive system.

A rat model biopsy showed that $\mathrm{PM}_{2.5}$ increased $\mathrm{OS}$ in the testes. First, expression of superoxide dismutase (SOD) decreased, which is one of the crucial enzymes that protect cells from reactive oxygen species (ROS). Second, an increase in heme oxygenase (HO) was observed. HO participates in ROS metabolism. An increased HO level signified increased OS [25].

Similarly, a testicular biopsy of $\mathrm{SO}_{2}$-exposed mice showed decreased expression of antioxidation enzymes, including SOD and glutathione peroxidase (GPx). GPx catalyzed the reduction of peroxide radicals to alcohols and oxygen and thereby reduced OS [7]. 


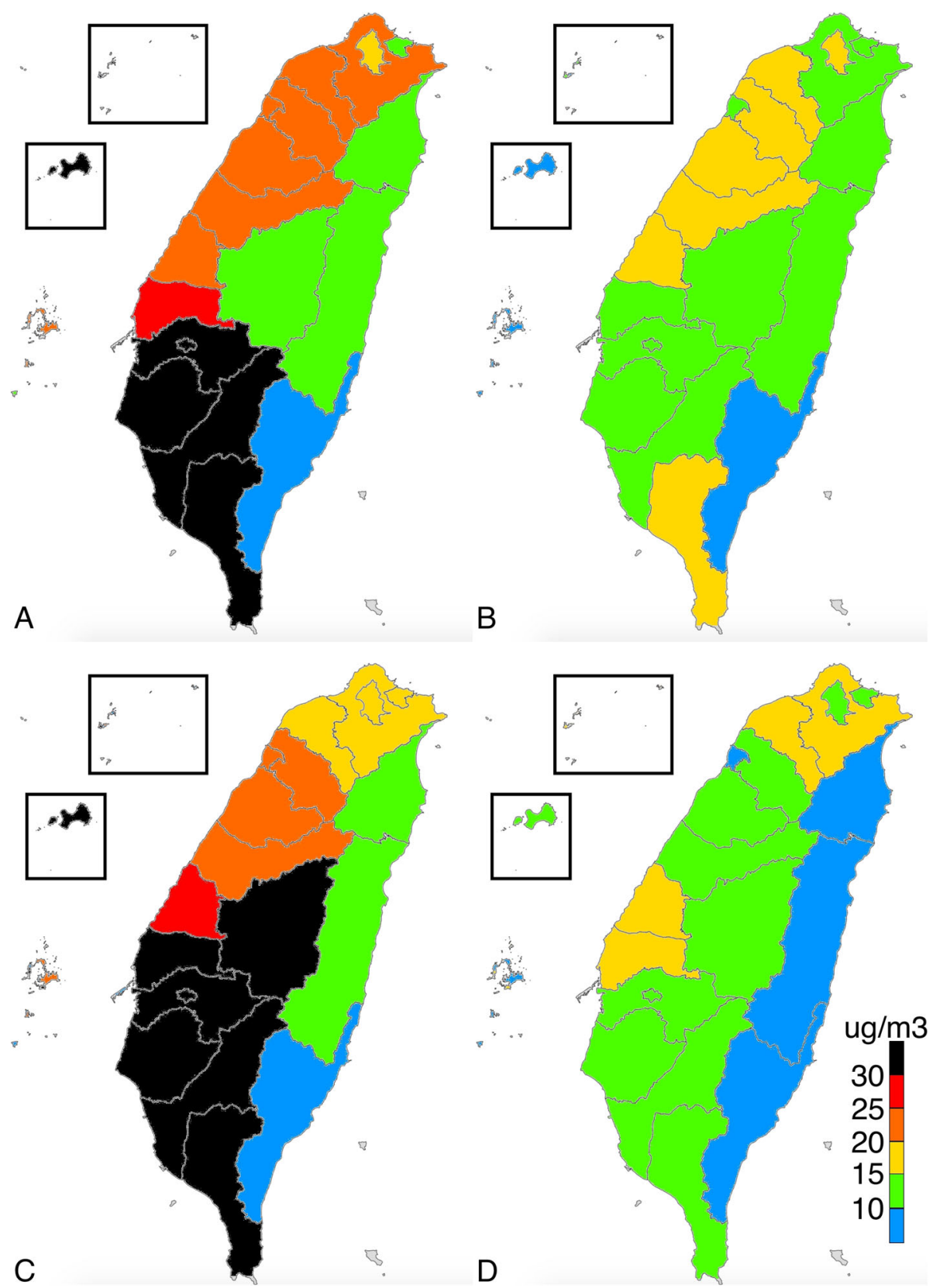

Fig. 1 Distribution of 2.5- $\mu$ m particulate matter in a January 2016; b July 2016; c January 2017; and d July 2017. (This work is adapted from the datasets of the National Land Surveying and Mapping Center MOI 2019-20, which is available to the public under the Open Government Data Licenses and is licensed under the Creative Commons Attribution-Share Alike 4.0 International license)

$\mathrm{NO}_{2}$ and $\mathrm{O}_{3}$ led to an increased expression of oxidative-stress-related gene, heme oxygenase (decycling) $1\left(\mathrm{HMOX}_{1}\right)$, which encodes $\mathrm{HO}$ in human bronchial epithelial cells. As aforementioned, an increased level of $\mathrm{HO}$ indicates increased OS. With exposure to $\mathrm{NO}_{2}$ and $\mathrm{O}_{3}$, the expression of $\mathrm{HMOX}_{1}$ and proinflammatory-related genes, including interleukin-6 and interleukin-8, increased [26]. More importantly, these molecules not only are deposited in the respiratory system but also travel to diverse organ systems through circulation [26-28].

OS and ROS could compromise male reproductive fucntion through altering the reproductive hormone profile and impairing spermatogenesis. ROS has been reported to be responsible for reduction in testosterone production, and a low testosterone level had a negative effect on spermatogenesis and male fertility [29-31]. Testosterone can protect the testicular microenvironment from 


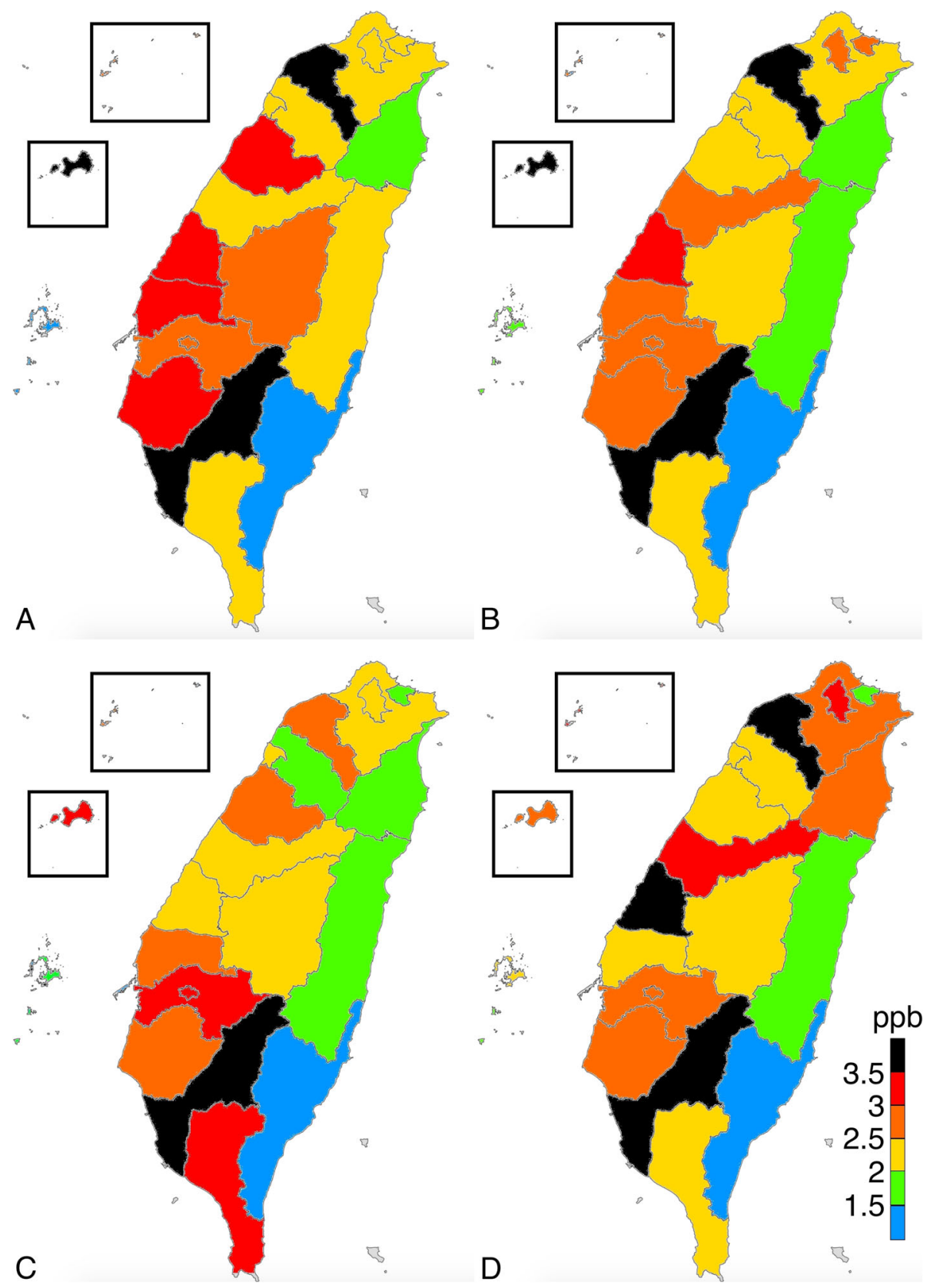

Fig. 2 Distribution of sulfur dioxide in a January 2016; b July 2016; c January 2017; and d July 2017. (This work is adapted from the datasets of the National Land Surveying and Mapping Center MOI 2019-20, which is available to the public under the Open Government Data Licenses and is licensed under the Creative Commons Attribution-Share Alike 4.0 International license)

damage by ROS [32, 33]. Activating hypothalamuspituitary-gonadal (HPG) axis with leptin in rat could induce high FSH and LH levels. High levels of FSH and LH were associated with high OS and DNA fragementation [34]. Similar results were reported by Beattie et al. after administering exogenous LH to rat Leydig cells [35]. ROS, on the other hand, downregulates the HPG axis through hormonal cross-link through activation of the hypothalamus-pituitary-adrenal axis. Cortisone secretion increased in response to increased stress, a high level of which suppresses FSH and LH secretion, finally leading to decreased testosterone production [31].

Exposing an animal model to air pollution reduced its testosterone level [36]. However, in the present study, the toxic ambient pollutants did not show a statistically significant effect on the sex hormone profile in our study population. Calogero el al reported similar results. Compared with the control group, Tollgate workers exposed 


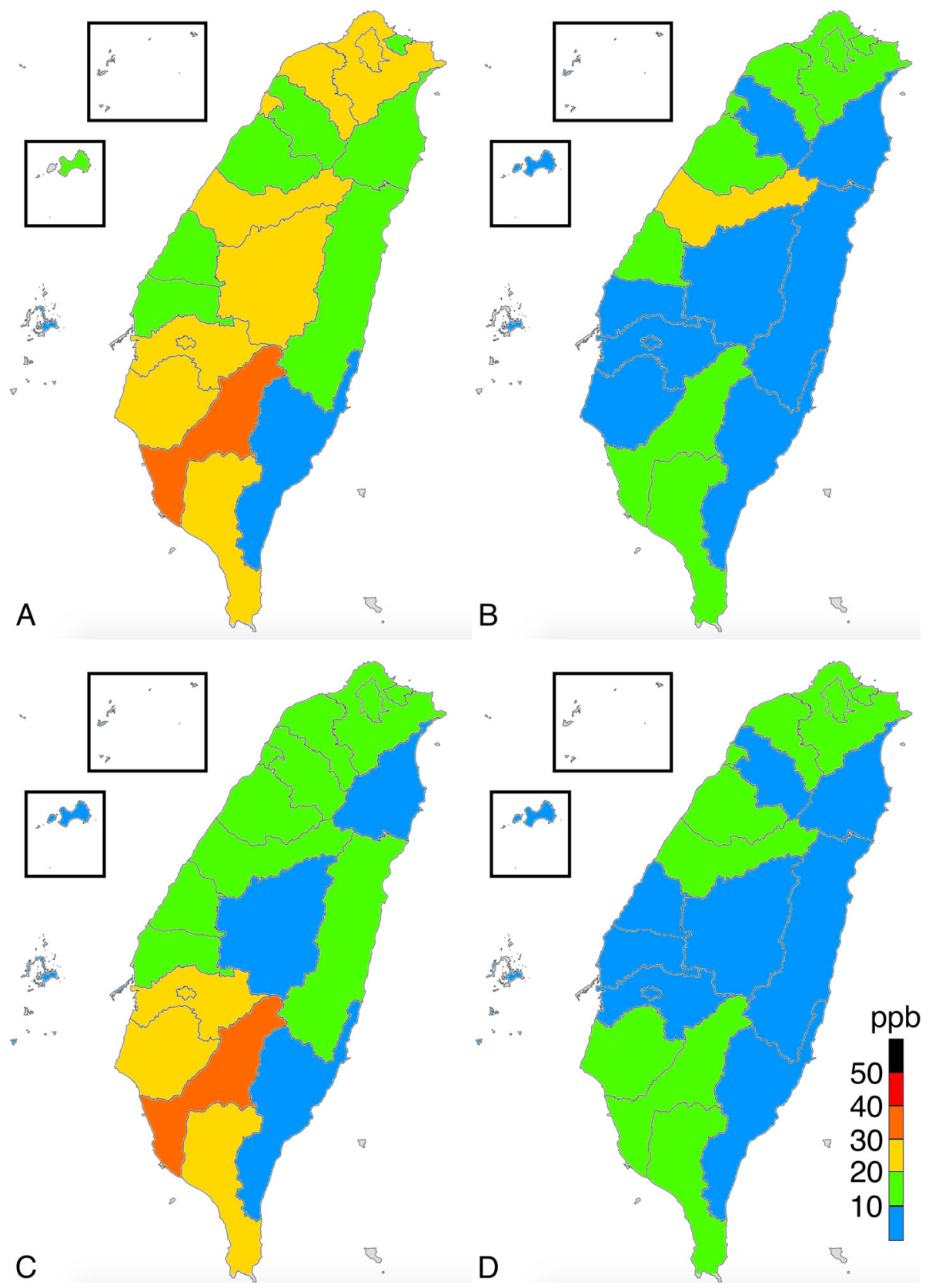

Fig. 3 Distribution of nitrogen oxides in a January 2016; b July 2016; c January 2017; and d July 2017. (This work is adapted from the datasets of the National Land Surveying and Mapping Center MOI 2019-20, which is available to the public under the Open Government Data Licenses and is licensed under the Creative Commons Attribution-Share Alike 4.0 International license)

to a high level of car exhaust did not have significantly different serum levels of LH, FSH, and testosterone [37]. However, additional studies are required to evaluate OS by using markers, such as SOD and GPx, after exposure to ambient pollutants to further establish the link between ambient pollutants, OS, and male sexual endocrinological function.

Spermatozoon is a cell type that generates ROS independently, which is crucial in the acrosome reaction
[38]. However, excessive ROS attacks the fluidity of the sperm plasma membrane and induces DNA damage in the sperm nucleus $[27,28]$. Moreover, spermatozoa are more vulnerable to OS than oocytes because they lack downstream enzymes that participate in base excision repair [7, 11, 39, 40]. Human testicular development mainly occurs during puberty, and different cell types, including Sertoli cells, spermatogonia, and spermatocytes, play a role. In childhood, the elongation of 


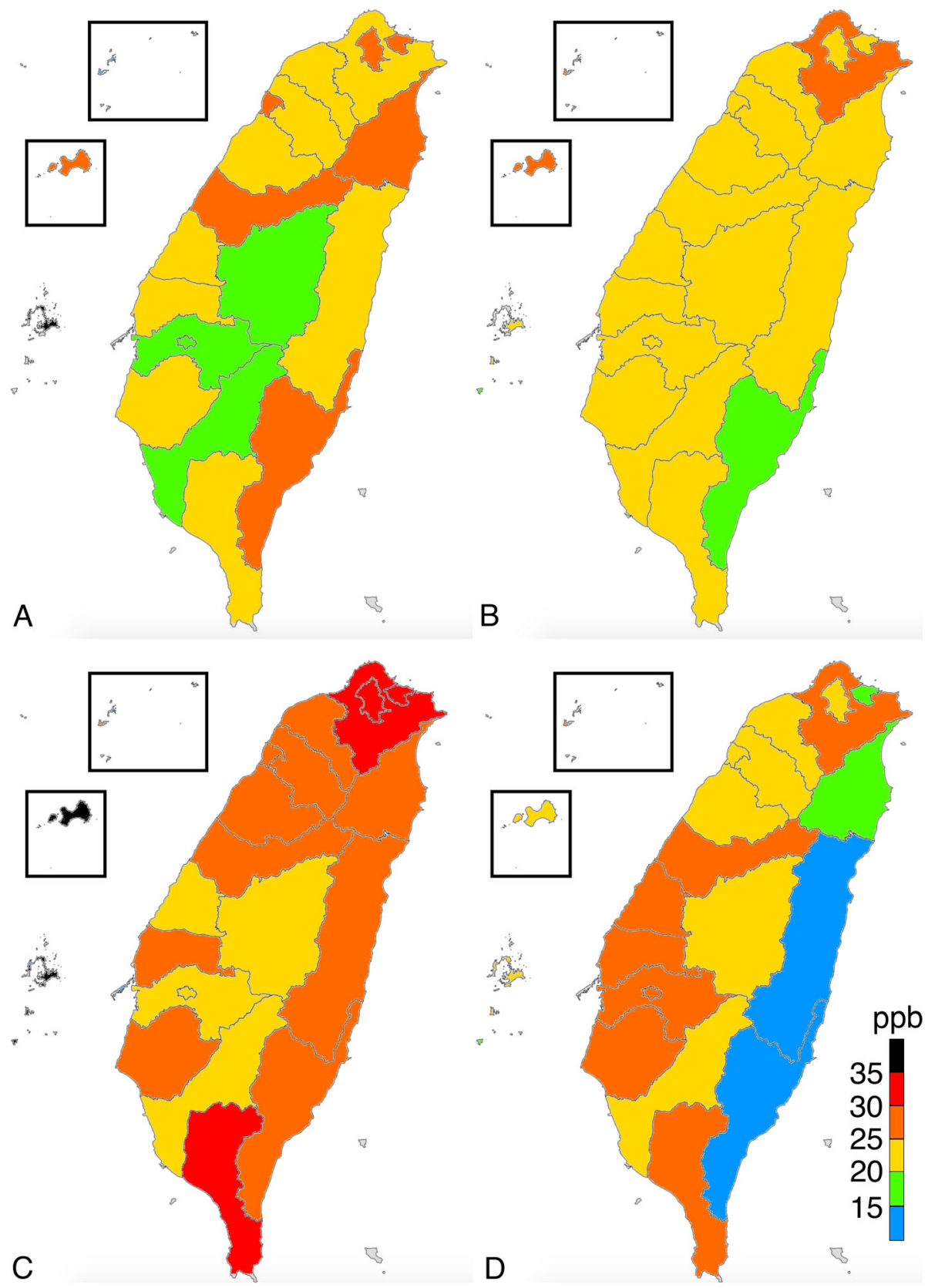

Fig. 4 Distribution of ozone in a January 2016; b July 2016; c January 2017; and d July 2017. (This work is adapted from the datasets of the National Land Surveying and Mapping Center MOI 2019-20, which is available to the public under the Open Government Data Licenses and is licensed under the Creative Commons Attribution-Share Alike 4.0 International license)

seminiferous tubules contributes to testicular growth. In puberty, the testicles enlarge due to increase in the diameter of the seminiferous tubules [41, 42]. Later, the exponential growth of germ cells during spermatogenesis increases the testicular volume $[21,43]$.

The effect of OS on testicular development was studied in mice models. Mice exposed to excessive OS caused by crotonaldehyde, a food preservative, had significantly low levels of GPx and SOD with an increased malondialdehyde (MDA) level, which was a direct indicator of lipid peroxidation-induced injury caused by ROS. Following increased ROS and OS, lower testicular and epididymal weights were observed in the experimental group [44]. Furthermore, mice exposed to doxorubicin-induced OS had similar outcomes. After a week's treatment, testicular volume, epididymal sperm count, and seminiferous tubule diameter decreased compared with the control group. 


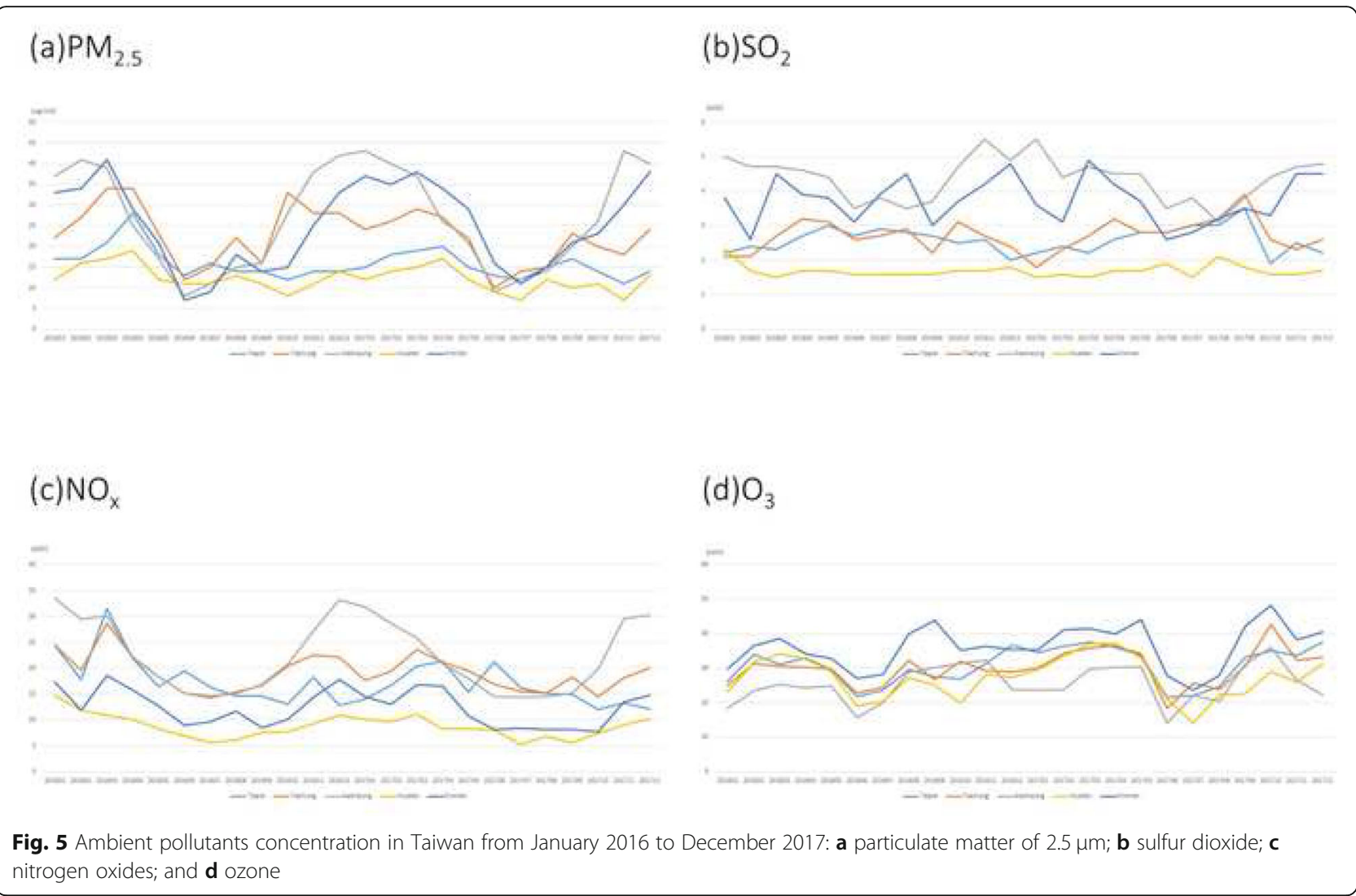

Excessive OS and lipid peroxidation can lead to germ cell damage and testicular degeneration [45-47].

Among humans, the effect of OS on the seminal parameter and testicular volume were studied in patients with varicocele. Patients with varicocele had higer OS levels than healthy controls, and testicular biopsy showed that the semiferous tubule diameters of patients with varicocele were reduced $[48,49]$. Hence, we adjusted the multivariate linear regression models with the presence of varicocele.

Our study could not evaluate the OS alteration in the male reproductive system that results from ambient pollutant exposure. A future study with OS markers from the semen testicular tissue after exposure to ambient pollution should be conducted. If semen quality and testicular volume change, the sperm structure should be observed in relation to increased OS to further establish the link between OS and the male reproductive system. In participants exposed to ambient pollutants, the enzymes that partake in redox could be analyzed, including SOD, GPx, MDA, and HO. Furthermore, DNA fragmentation could be analyzed, as it has been reported to result from OS and could lead to sperm apoptosis [27, 28, $38,50]$.
To our knowledge, this is the first study to evaluate the effects of ambient pollutants on the testicular volume of men with infertility. Nevertheless, the current study has several limitations. First, we considered the exposure variation based on daily average exposure concentrations for a specific period ( 2 years) while ignoring the effects of the peak and exposure of certain pollutants within a day. Additionally, we estimated individual exposure based on the residential address record at the clinic. This ignored occupational exposure, which could be a serious confounding factor when occupational exposure to air pollution is profound; for example, if a participant is a factory worker. Moreover, if the patient spends only a little time at home, estimating the exposure based on residential address could be misleading. Second, our study was retrospective and observatory in design because intentionally exposing participants to air pollutants is unethical. Moreover, the present study lacked serum or seminal marker for OS, which we believe participates in the alteration of seminal parameter and testicular volume. We aim to conduct further studies by using surrogate markers to determine OS in the semen and testicular tissue of patients with infertility who needed testicle biopsy. Third, our study population 
Table 3 Multivariable linear regression by using a sperm parameter for exposure to ambient pollutants

\begin{tabular}{lll}
\hline $\begin{array}{l}\text { Sperm } \\
\text { parameters }\end{array}$ & $\begin{array}{l}\text { Regression coefficients (95\% confidence } \\
\text { interval) }\end{array}$ & $\begin{array}{l}p \\
\text { value }\end{array}$ \\
\hline $\begin{array}{l}\text { Sperm count } \\
\text { PM2.5 }\end{array}$ & $0.896(-16.113$ to 40.225$)$ & 0.382 \\
$\mathrm{SO}_{2}$ & $-0.891(-169.427$ to 68.260$)$ & 0.384 \\
$\mathrm{NOx}$ & $-1.136(-12.614$ to 3.738$)$ & 0.270 \\
$\mathrm{O}_{3}$ & $-0.196(-18.947$ to 15.698$)$ & 0.846
\end{tabular}

Sperm concentration

$\begin{array}{ll}\mathrm{PM} 2.5 & 0.109(-13.821 \text { to } 15.340) \\ \mathrm{SO}_{2} & -1.302(-99.796 \text { to } 23.235) \\ \mathrm{NOx} & -2.174(-8.627 \text { to }-0.164) \\ \mathrm{O}_{3} & -1.749(-16.458 \text { to } 1.475)\end{array}$

Sperm motility

$\begin{array}{ll}\mathrm{PM} 2.5 & -0.303(-7.508 \text { to } 5.608) \\ \mathrm{SO}_{2} & 0.049(-27.026 \text { to } 28.308) \\ \mathrm{NOx} & -2.321(-4.014 \text { to }-0.207) \\ \mathrm{O}_{3} & -1.248(-6.437 \text { to } 1.624)\end{array}$

Sperm normal form

\begin{tabular}{cll}
$\mathrm{PM} 2.5$ & $1.248(-3.566$ to 13.322$)$ & 0.234 \\
$\mathrm{SO}_{2}$ & $-0.617(-46.216$ to 25.681$)$ & 0.548 \\
$\mathrm{NOx}$ & $1.400(-1.147$ to 5.369$)$ & 0.185 \\
$\mathrm{O}_{3}$ & $0.992(-4.546$ to 12.267$)$ & 0.339 \\
\hline${ }^{*} p<0.05$ &
\end{tabular}

Table 4 Multivariable linear regression by using sex hormone for exposure to ambient pollutants

\begin{tabular}{|c|c|c|}
\hline $\begin{array}{l}\text { Sex } \\
\text { hormone }\end{array}$ & $\begin{array}{l}\text { Regression coefficients ( } 95 \% \text { confidence } \\
\text { interval) }\end{array}$ & $p$ value \\
\hline \multicolumn{3}{|l|}{$\overline{\mathrm{FSH}}$} \\
\hline PM2.5 & $0.073(-0.651$ to 0.931$)$ & 0.704 \\
\hline $\mathrm{SO}_{2}$ & $0.262(-2.613$ to 7.24$)$ & 0.324 \\
\hline NOx & $-0.431(-0.218$ to 0.004$)$ & 0.057 \\
\hline $\mathrm{O}_{3}$ & $0.122(-0.503$ to 0.852$)$ & 0.582 \\
\hline Age & 1.053 (0.290 to 0.639$)$ & $\begin{array}{l}< \\
0.01^{* *}\end{array}$ \\
\hline \multicolumn{3}{|l|}{ LH } \\
\hline PM2.5 & $0.014(-0.357$ to 0.371$)$ & 0.966 \\
\hline $\mathrm{SO}_{2}$ & $0.170(-1.857$ to 2.680$)$ & 0.697 \\
\hline NOx & $0.276(-0.032$ to 0.070$)$ & 0.436 \\
\hline $\mathrm{O}_{3}$ & $0.559(-0.093$ to 0.531$)$ & 0.150 \\
\hline \multicolumn{3}{|c|}{ Testosterone } \\
\hline PM2.5 & $0.052(-0.50$ to 0.576$)$ & 0.880 \\
\hline $\mathrm{SO}_{2}$ & $-0.376(-4.572$ to 2.042$)$ & 0.421 \\
\hline NOx & $0.156(-0.061$ to 0.090$)$ & 0.678 \\
\hline $\mathrm{O}_{3}$ & $-0.044(-0.469$ to 0.424$)$ & 0.914 \\
\hline
\end{tabular}

Abbreviations: FSH Follicle Stimulating Hormone, $L H$ Luteinizing hormone, ${ }^{* *} p<0.01$
Table 5 Multivariable linear regression by using the testicular volume for exposure of ambient pollutant

\begin{tabular}{|c|c|c|}
\hline & Regression coefficients (95\% confidence interval) & $p$ value \\
\hline \multicolumn{3}{|c|}{ Right testicle } \\
\hline PM2.5 & $-0.472(-0.956$ to 0.607$)$ & 0.643 \\
\hline $\mathrm{SO}_{2}$ & $-3.101(-8.279$ to -1.575$)$ & $0.006^{* *}$ \\
\hline $\mathrm{NOx}$ & $-0.967(-0.376$ to 0.140$)$ & 0.347 \\
\hline $\mathrm{O}_{3}$ & $-1.337(-1.007$ to 0.226$)$ & 0.199 \\
\hline \multicolumn{3}{|c|}{ Left testicle } \\
\hline PM2.5 & $0.472(-0.956$ to 0.607$)$ & 0.643 \\
\hline $\mathrm{SO}_{2}$ & $-3.101(-8.279$ to -1.575$)$ & $0.006^{* *}$ \\
\hline $\mathrm{NOx}$ & $-0.967(-0.376$ to 0.140$)$ & 0.347 \\
\hline $\mathrm{O}_{3}$ & $-1.337(-1.007$ to 0.226$)$ & 0.199 \\
\hline
\end{tabular}

0.765

0.962

$0.032^{*}$

0.227

0.234

0.548

339

.

\section{healt} health examination during college entrance, are recommended to strengthen the statistical power.

\section{Conclusions}

The result of the present study suggests that ambient $\mathrm{NO}_{\mathrm{x}}$ are a risk factor for poor sperm motility and decreased sperm concentration. Moreover, exposure to

Table 6 Multivariable linear regression by using the testicular volume for exposure of ambient pollutant after adjusting for sex hormone

\begin{tabular}{|c|c|c|}
\hline & Regression coefficients ( $95 \%$ confidence interval) & $p$ value \\
\hline \multicolumn{3}{|c|}{ Right testicle } \\
\hline PM2.5 & $0.147(-0.492$ to 1.031$)$ & 0.476 \\
\hline $\mathrm{SO}_{2}$ & $-0.520(-4.696$ to -0.0474$)$ & $0.018^{*}$ \\
\hline NOx & $0.170(-0.067$ to 0.155$)$ & 0.424 \\
\hline $\mathrm{O}_{3}$ & $-0.188(-0.834$ to 0.317$)$ & 0.366 \\
\hline \multicolumn{3}{|c|}{ Left testicle } \\
\hline PM2.5 & $0.141(-0.465$ to 0.929$)$ & 0.502 \\
\hline $\mathrm{SO}_{2}$ & $-0.506(-4.193$ to -0.328$)$ & $0.023^{*}$ \\
\hline NOx & $0.199(-0.055$ to 0.147$)$ & 0.362 \\
\hline $\mathrm{O}_{3}$ & $-0.009(-0.538$ to 0.516$)$ & 0.967 \\
\hline
\end{tabular}


$\mathrm{SO}_{2}$ was negatively associated with testicular volume. However, the strength of the result is limited by the retrospective nature and small sample size of the study. Future prospective studies with healthy control and oxidative markers should be conducted to further establish the cause-effect relation between ambient pollutants and the male reproductive system and determine the mechanism behind it.

\begin{abstract}
Abbreviations
WHO: World Health Organization; Ppb: Parts per billion; $\mathrm{PM}_{2.5}$ : Particulate matters 2.5; $\mathrm{O}_{3}$ : Ozone; $\mathrm{SO}_{2}$ : Sulfur dioxide; NO: Nitrogen monoxide; $\mathrm{NO}_{2}$ : Nitrogen dioxide; FSH: Follicle stimulating hormone; LH: Luteinizing hormone; BMI: Body mass index; SOD: Superoxide dismutase; HO: Heme oxygenase; ROS: Reactive oxygen species; $\mathrm{HMOX}_{1}$ : Heme oxygenase (decycling) 1; GPx: Glutathione peroxidase; MDA: Malondialdehyde; NOx: Nitrogen oxides; OS: Oxidative stress; HPG: Hypothalamus-pituitarygonadal
\end{abstract}

\section{Acknowledgements}

This manuscript was edited for language by Wallace Academic Editing.

\section{Authors' contributions}

HC Chang and YK Chang conceived the study design and contributed to data collection. YA Chen analyzed and interpreted the patient data regarding the sperm and physical examination and was a major contributor in writing the manuscript. HC Chang and YK Chang revised the article. All authors read and approved the final manuscript.

\section{Funding}

No funding was received from any commercial or government source.

\section{Availability of data and materials}

The datasets used in the current study can be obtained from the corresponding author on reasonable request.

\section{Ethics approval and consent to participate}

This was a retrospective observational study. The institutional review board of the National Taiwan University approved our study and waived the informed consent requirement because of the retrospective design of our study (IRB number: 20190311 RIND).

\section{Consent for publication}

Not applicable.

\section{Competing interests}

The authors declare that they have no competing interests.

\section{Author details}

'Department of Urology, National Taiwan University Hospital and National Taiwan University College of Medicine, No.1, Changde St., Zhongzheng Dist, Taipei City 10048, Taiwan. ${ }^{2}$ Department of Urology, Cardinal Tien Hospital, School of Medicine Fu-Jen Catholic University, No.362, Zhongzheng Rd. Xindian Dist, New Taipei City 231, Taiwan. ${ }^{3}$ Department of Urology, National Taiwan University Hospital Hsin-Chu Branch, NO.25, Lane 442, Sec.1, Jingguo Rd, Hsinchu City 300, Taiwan.

Received: 1 January 2020 Accepted: 26 August 2020

Published online: 02 October 2020

\section{References}

1. Sengupta P. Environmental and occupational exposure of metals and their role in male reproductive functions. Drug Chem Toxicol. 2013;36(3):353-68.

2. Sengupta P, Banerjee R. Environmental toxins: alarming impacts of pesticides on male fertility. Hum Exp Toxicol. 2013;33(10):1017-39.

3. Ruth De Celis MS, Feria-Velasco A, Marco Gonza' lez-Unzaga MS, TorresCalleja J, Pedro' n-Nuevo N. Semen quality of workers occupationally exposed to hydrocarbons. Fertil Steril. 2000;73(2):221-8.
4. Nieuwenhuijsen MJ, Basagaña X, Dadvand P, Martinez D, Cirach M, Beelen R, et al. Air pollution and human fertility rates. Environ Int. 2014;70:9-14.

5. Frutos V, González-Comadrán M, Solà I, Jacquemin B, Carreras R, Checa Vizcaíno MA. Impact of air pollution on fertility: a systematic review. Gynecol Endocrinol. 2015;31(1):7-13.

6. Farhat J, Farhat SCL, Braga ALF, Cocuzza M, Borba EF, Bonfá E, et al. Ozone decreases sperm quality in systemic lupus erythematosus patients. Rev Bras Reumatol Engl Ed. 2016;56(3):212-9.

7. Meng Z, Bai W. Oxidation damage of sulfur dioxide on testicles of mice. Environ Res. 2004;96(3):298-304.

8. Pires A, de Melo EN, Mauad T, Nascimento Saldiva PH, de Siqueira Bueno HM. Pre- and postnatal exposure to ambient levels of urban particulate matter (PM2.5) affects mice spermatogenesis. Inhal Toxicol. 2011;23(4):237-45.

9. Boggia B, Carbone U, Farinaro E, et al. Effects of working posture and exposure to traffic pollutants on sperm quality. J Endocrinol Investig. 2009; 32(5):430-4

10. Zhou N, Cui Z, Yang S, Han X, Chen G, Zhou Z, et al. Air pollution and decreased semen quality: A comparative study of Chongqing urban and rural areas. Environ Pollut. 2014;187:145-52.

11. Wei $Y$, Cao X-N, Tang X-L, Shen L-J, Lin T, He D-W, et al. Urban fine particulate matter (PM2.5) exposure destroys blood-testis barrier (BTB) integrity through excessive ROS-mediated autophagy. Toxicol Mech Methods. 2017:28(4):302-19.

12. Zhang J, Zheng F, Liang C, Zhu Y, Shi Y, Han Y, et al. Sulfur dioxide inhalation lowers sperm quality and alters testicular histology via increasing expression of CREM and ACT proteins in rat testes. Environ Toxicol Pharmacol. 2016;47:47-52.

13. Hansen C, Luben TJ, Sacks JD, Olshan A, Jeffay S, Strader L, et al. The effect of ambient air pollution on sperm quality. Environ Health Perspect. 2010; 118(2):203-9.

14. Selevan SG, Borkovec L, Slott VL, Zudová Z, Rubes J, Evenson DP, et al. Semen quality and reproductive health of young Czech men exposed to seasonal air pollution. Environ Health Perspect. 2000;108(9):887-94.

15. Liu Y, Zhou Y, Ma J, Bao W, Li J, Zhou T, et al. Inverse association between ambient sulfur dioxide exposure and semen quality in Wuhan, China. Environ Sci Technol. 2017:51(21):12806-14.

16. Zhang HT, Zhang Z, Cao J, Tang WH, Zhang HL, Hong K, et al. Ambient ozone pollution is associated with decreased semen quality: Iongitudinal analysis of 8945 semen samples from 2015 to 2018 and during pollutioncontrol period in Beijing, China. Asian J Androl. 2019;21(5):501-7.

17. Nobles CJ, Schisterman EF, Ha S, Kim K, Mumford SL, Buck Louis GM, et al. Ambient air pollution and semen quality. Environ Res. 2018;163:228-36.

18. Cooper TG, Noonan E, von Eckardstein S, Auger J, Baker HWG, Behre HM, et al. World Health Organization reference values for human semen characteristics**. Hum Reprod Update. 2009;16(3):231-45.

19. Menkveld R. Clinical significance of the low normal sperm morphology value as proposed in the fifth edition of the WHO Laboratory manual for the examination and processing of human semen. Asian J Androl. 2010; 12(1):47-58

20. Mulhall JP, Trost LW, Brannigan RE, Kurtz EG, Redmon JB, Chiles KA, et al. Evaluation and Management of Testosterone Deficiency: AUA guideline. J Urol. 2018;200(2):423-32

21. Krzyzanowski M, Cohen A. Update of WHO air quality quidelines. Air Qual Atmos Health. 2008;1(1):7-13.

22. Wdowiak A, Wdowiak E, Bien A, Bojar I, Iwanowicz-Palus G, Raczkiewicz D. Air pollution and semen parameters in men seeking fertility treatment for the first time. Int J Occup Med Environ Health. 2019:32(3):387-99.

23. Fathi Najafi T, Latifnejad Roudsari R, Namvar F, Ghavami Ghanbarabadi V, Hadizadeh Talasaz Z, Esmaeli M. Air Pollution and Quality of Sperm: A MetaAnalysis. Iran Red Crescent Med J. 2015;17(4):e26930.

24. Sokol RZ, Kraft P, Fowler IM, Mamet R, Kim E, Berhane KT. Exposure to environmental ozone alters semen quality. Environ Health Perspect. 2006; 114(3):360-5.

25. Wei $Y$, Cao X-N, Tang X-L, Shen L-J, Lin T, He D-W, et al. Urban fine particulate matter (PM2.5) exposure destroys blood-testis barrier (BTB) integrity through excessive ROS-mediated autophagy. Toxicol Mech Methods. 2018;28(4):302-19.

26. Mirowsky JE, Dailey LA, Devlin RB. Differential expression of proinflammatory and oxidative stress mediators induced by nitrogen dioxide and ozone in primary human bronchial epithelial cells. Inhal Toxicol. 2016; 28(8):374-82. 
27. Aitken J, Fisher H. Reactive oxygen species generation and human spermatozoa: the balance of benefit and risk. BioEssays. 1994;16(4):259-67.

28. Agarwal A, Saleh RA, Bedaiwy MA. Role of reactive oxygen species in the pathophysiology of human reproduction. Fertil Steril. 2003;79(4):829-43.

29. Kahn BE, Brannigan RE. Obesity and male infertility. Curr Opin Urol. 2017; 27(5):441-5.

30. Syriou V, Papanikolaou D, Kozyraki A, Goulis DG. Cytokines and male infertility. Eur Cytokine Netw. 2018;29(3):73-82.

31. Darbandi M, Darbandi S, Agarwal A, Sengupta P, Durairajanayagam D, Henkel $R$, et al. Reactive oxygen species and male reproductive hormones. Reprod Biol Endocrinol. 2018;16(1):87.

32. Chainy GB, Samantaray S, Samanta L. Testosterone-induced changes in testicular antioxidant system. Andrologia. 1997;29(6):343-9.

33. Shang $X$, Huang $Y, Y$, Z, Yu X, Gu W. Protection of melatonin against damage of sperm mitochondrial function induced by reactive oxygen species. Zhonghua Nan Ke Xue. 2004;10(8):604-7.

34. Abbasihormozi S, Shahverdi A, Kouhkan A, Cheraghi J, Akhlaghi AA, Kheimeh A. Relationship of leptin administration with production of reactive oxygen species, sperm DNA fragmentation, sperm parameters and hormone profile in the adult rat. Arch Gynecol Obstet. 2013;287(6):1241-9.

35. Beattie MC, Chen H, Fan J, Papadopoulos V, Miller P, Zirkin BR. Aging and luteinizing hormone effects on reactive oxygen species production and DNA damage in rat Leydig cells. Biol Reprod. 2013;88(4):100.

36. Sobolewski M, Anderson T, Conrad K, Marvin E, Klocke C, Morris-Schaffer K, et al. Developmental exposures to ultrafine particle air pollution reduces early testosterone levels and adult male social novelty preference: risk for children's sex-biased neurobehavioral disorders. NeuroToxicology. 2018;68:203-11.

37. Calogero AE, La Vignera S, Condorelli RA, Perdichizzi A, Valenti D, Asero P, et al. Environmental car exhaust pollution damages human sperm chromatin and DNA. J Endocrinol Investig. 2011;34(6):e139-43.

38. Dutta S, Henkel R, Sengupta P, Agarwal A. Physiological Role of ROS in Sperm Function. Male Infertility. 2020:337-45.

39. Aitken RJ, Smith TB, Jobling MS, Baker MA, De luliis GN. Oxidative stress and male reproductive health. Asian J Androl. 2014;16(1):31-8.

40. Cao XN, Shen LJ, Wu SD, Yan C, Zhou Y, Xiong G, et al. Urban fine particulate matter exposure causes male reproductive injury through destroying blood-testis barrier (BTB) integrity. Toxicol Lett. 2017;266:1-12.

41. Koskenniemi JJ, Virtanen HE, Toppari J. Testicular growth and development in puberty. Curr Opin Endocrinol Diabetes Obes. 2017;24(3):215-24.

42. Cortes D, Müller J, Skakkebaek NE. Proliferation of Sertoli cells during development of the human testis assessed by stereological methods. Int J Androl. 1987:10(4):589-96.

43. Rodolfo A, Rey SMC, Bedecarras P, Nagle CA, Hetor E. CHEMES is infancy a quiescent period of testicular development? Histological, morphometric, and functional study of the seminiferous tubules of the Cebus monkey from birth to the end of puberty. J Clin Endocrmol Metab. 1993;76(5):1325-31.

44. Li SSZB, Zhang ZH. Study on oxidative stress damage of reproductive organs in male rats induced by long-term exposure to crotonaldehyde. Chin J Ind Hygiene Occup Dis. 2019;37(4):241-6.

45. Farsani BE, Karimi S, Mansouri E. Pravastatin attenuates testicular damage induced by doxorubicin - a stereological and histopatological study. J Basic Clin Physiol Pharmacol. 2018;30(1):103-9.

46. Mirzaei Khorramabadi K, Reza Talebi A, Abbasi Sarcheshmeh A, Mirjalili A Protective effect of vitamin $\mathrm{E}$ on oxidative stress and sperm apoptosis in diabetic mice. Int J Reprod Biomed (Yazd). 2019;17(2):127-34

47. Koksal IT, Usta M, Orhan I, Abbasoglu S, Kadioglu A. Potential role of reactive oxygen species on testicular pathology associated with infertility. Asian J Androl. 2003;5(2):95-9.

48. Agarwal A, Makker K, Sharma R. Clinical relevance of oxidative stress in male factor infertility: an update. Am J Reprod Immunol. 2008;59(1):2-11.

49. Boujbiha MA, Hamden K, Guermazi F, Bouslama A, Omezzine A, Kammoun $A$, et al. Testicular toxicity in mercuric chloride treated rats: association with oxidative stress. Reprod Toxicol. 2009;28(1):81-9.

50. Muratori M, Tamburrino L, Marchiani S, Cambi M, Olivito B, Azzari C, et al. Investigation on the origin of sperm DNA fragmentation: role of apoptosis, Immaturity and Oxidative Stress. Mol Med. 2015;21(1):109-22.

\section{Publisher's Note}

Springer Nature remains neutral with regard to jurisdictional claims in published maps and institutional affiliations.

Ready to submit your research? Choose BMC and benefit from:

- fast, convenient online submission

- thorough peer review by experienced researchers in your field

- rapid publication on acceptance

- support for research data, including large and complex data types

- gold Open Access which fosters wider collaboration and increased citations

- maximum visibility for your research: over $100 \mathrm{M}$ website views per year

At $\mathrm{BMC}$, research is always in progress.

Learn more biomedcentral.com/submissions 